\title{
The effect of "TB Mataho" health cadres in improving self-care capacity of patients with pulmonary tuberculosis
}

\author{
Muhtar Muhtar $^{1}$, Aniharyati Aniharyati ${ }^{1}$
}

1 Jurusan Keperawatan, Poltekkes Kemenkes Mataram, Indonesia

\begin{tabular}{|c|c|}
\hline Article Info & Abstract \\
\hline $\begin{array}{l}\text { Article History: } \\
\text { Submitted: June } 7^{\text {th }}, 2021 \\
\text { Accepted: Oct } 27^{\text {th }}, 2021 \\
\text { Published: Nov } 25^{\text {th }}, 2021 \\
\text { Keywords: } \\
\text { tuberculosis; tuberculosis } \\
\text { survivors; self-care capacity; } \\
\text { Health cadre }\end{array}$ & $\begin{array}{l}\text { TB is still a public health problem throughout the world where Indonesia is } \\
\text { a country that has the third largest number of TB sufferers after India and } \\
\text { China. Self-care by patients and families during the treatment process was } \\
\text { the key to healing pulmonary TB. Using a quasi-experimental method, this } \\
\text { study aims to improve the ability of self-care for pulmonary TB patients } \\
\text { through intervention by "TB Mataho" health cadres. Most of the self-care } \\
\text { capacity of pulmonary TB patients with pre-test results were sufficient, in } \\
\text { the treatment group ( } 75.2 \% \text { ) and the control group ( } 62.5 \%) \text {. The post-test } \\
\text { results for the treatment group were in the good category (53.1\%) and the } \\
\text { control group was in the sufficient category ( } 59.4 \%) \text {. The results of the } \\
\text { Paired Samples Test analysis in the treatment group obtained a value of p = } \\
\text { 0.001 (p <0.05), which means that there was a significant difference in self- } \\
\text { care capacity of pulmonary TB patients before and after treatment, as well } \\
\text { as the results of the Independent Samples Test analysis, the p value was } \\
\text { obtained. 0.030 (p <0.05) which means that there was a significant } \\
\text { difference in the post-test results in the treatment group and the control } \\
\text { group. Researchers recommend that pulmonary TB survivors who have a } \\
\text { basic education of secondary and above can be trained to become health } \\
\text { cadres and share their successful experiences with pulmonary TB patients } \\
\text { who are still undergoing treatment programs.. }\end{array}$ \\
\hline
\end{tabular}

\section{PENDAHULUAN}

Tuberkulosis (TB) adalah penyakit lama yang telah mempengaruhi manusia selama ribuan tahun [1], penyebabnya masih belum diketahui sampai 24 Maret 1882, ketika Dr Robert Koch mengumumkan bahwa dia telah menemukan bacillus Mycobacterium tuberculosis [2]. Sampai saat ini penyakit TB masih merupakan masalah kesehatan masyarakat di seluruh dunia dimana Indonesia merupakan negara yang mempunyai beban TB yang terbesar ketiga setelah India dan China [3]. Selain itu terdapat tantangan yang perlu menjadi perhatian yaitu meningkatnya kasus TBMDR (multi drug resisten), TB-HIV (Human Immunodevisiensi Virus), TB dengan Diabetes Mellitus, TB pada anak dan masyarakat rentan lainnya [4]. Di Indonesia angka notifikasi (Case Notification Rate/CNR) semua kasus tuberkulosis pada tahun 2017 sebesar 162 per 100.000 penduduk meningkat dibandingkan tahun

Corresponding author:

Muhtar Muhtar

muhtarbima@gmail.com

Media Keperawatan Indonesia, Vol 4 No 4, November 2021

e-ISSN: 2615-1669

ISSN: 2722-2802

DOI: $10.26714 / \mathrm{mki} .4 .4 .2021 .256-263$ 
2016 sebesar 139 per 100.000 penduduk [4]. Di Kota Bima, angka penemuan kasus (Case Detection Rate/CDR) TB paru masih rendah yaitu sebesar $29,6 \%$ masih dibawah CDR nasional sebesar $42,8 \%$, pada tahun 2017 jumlah penderita TB dilaporkan sebanyak 282 kasus meningkat dari tahun 2016 sebanyak 206 kasus, dengan angka pengobatan lengkap sebesar 47,81\% dan angka kesembuhan sebesar 47,81\%. [5].

Intervensi perawatan kesehatan utama untuk mencegah penyakit TB adalah pengobatan tuntas penderita yang sudah terdiagnosis dan pemberian vaksinasi BCG (bacille Calmette-Guérin) pada bayi [3]. Di kota Bima program pemberantasan penyakit TB paru telah menerapkan strategi DOTS (Direct Observed Treatment Shortcourse) dengan penemuan kasus secara pasif melalui promosi aktif. Hasil wawancara dengan petugas TB di dinas kesehatan Kota Bima pada bulan Maret 2019 mengemukakan beberapa permasalah yang menjadi kendala dalam pemberantasan TB paru antara lain masih kuatnya stigma di masyarakat yang memandang TB sebagai penyakit yang memalukan sehingga mereka menyembunyikan penyakit yang mereka derita, kurangnya pengetahuan tentang penyakit TB paru serta kendala ekonomi keluarga dan kebiasaan masyarakat pinggiran Kota Bima yang bekerja sebagai petani jangung tinggal diladang mereka selama musim tanam sampai panen sehingga sulit untuk dijangkau oleh petugas kesehatan. Hal ini berdampak pada rendahnya penemuan kasus, pengobatan dan perawatan diri penderita TB paru.

Kurangnya kepatuhan terhadap pengobatan menjadi hambatan utama untuk pengendalian TB yang efisien di negara berkembang, diperlukan strategi inovatif untuk meningkatkan akses dan kepatuhan terhadap pengobatan [6]. Berbagai upaya telah dilakukan untuk mengendalikan TB paru dengan meningkatkan penemuan kasus dan pengobatan penderita yang melibatkan peran serta masyarakat seperti hasil penelitian Datiko \& Lindtjorn [7] yang melibatkan petugas penyuluhan kesehatan masyarakat (HEW : Health Extension Workers) dalam pengendalian TB, yang dapat meningkatkan deteksi kasus BTApositif dan tingkat keberhasilan pengobatan di Ethiopia selatan. Selanjutnya [8] mengusulkan perlunya peran serta masyarakat dalam meningkatkan kesejahteraan mental dan sosial pasien TB melalui tiga tema utama yaitu peringatan, perawatan dan pendidikan untuk mengendalikan situasi TB di India.

Perawatan diri sebagai konsep penting dalam keperawatan, adalah sebuah proses di mana orang awam bertindak atas nama mereka sendiri untuk mempromosikan dan menjaga kesehatan mereka, mendeteksi penyakit apa pun yang mungkin mereka miliki, dan menyediakan atau mendapatkan pengobatan untuk penyakit mereka [9]. Perawat bertanggung jawab untuk memberikan asuhan keperawatan kepada keluarga dengan merancang intervensi keperawatan interaktif yang dapat membantu keluarga mengoptimalkan sumber daya keluarga untuk merawat anggota keluarga mereka [10]. Salah satunya melalui keterlibatan pekerja kesehatan masyarakat (CHW: community health worker) sesuai hasil penelitian [11] bahwa intervensi CHW yang berpusat pada pasien meningkatkan akses ke perawatan primer dan kualitas pemulangan pada populasi yang beresiko tinggi. Disamping itu dari sudut pandang pasien, pemberdayaan masyarakat sebagai pekerja kesehatan menjadikan pasien merasa termotivasi dan lebih mudah untuk mengambil dan mengelola perawatan mereka di rumah [12].

Perilaku perawatan diri dan perawatan mandiri (self care) yang dilakukan oleh pasien dan keluarga selama proses pengobatan merupakan kunci kesembuhan dan keberhasilan pengobatan lengkap TB paru yang berlangsung 6 sampai 9 bulan [13]. Salah satu upaya untuk meningkatkan 
kemampuan perawatan diri (self care capacity) penderita TB paru adalah melalui pemberdayaan masyarakat sebagai pekerja kesehatan, penelitian ini bertujuan memberdayakan para penyintas TB paru yang telah dinyatakan sembuh sebagai kader kesehatan yang bertugas menemukan kasus TB di masyarakat, serta membantu memberikan pendampingan untuk meningkatkan kemampuan perawatan diri penderita selama menjalani pengobatan TB paru.

\section{METODE}

Penelitian ini adalah penelitian kuntitatif yang menggunakan desain quasi eksperimental dengan rancangan yang digunakan adalah pretest-posttest with control group. Populasi dalam penelitian ini adalah semua penderita TB paru yang terdaftar dan menjalani pengobatan di wilayah kerja Dinas Kesehatan Kota Bima selama tahun 2019, responden yang terlibat telah menjalani pengobatan minimal 1 bulan dan maksimal 5 bulan. Penentuan besar sampel pada penelitian ini menggunkan rumus penghitungan besar sampel dua kelompok berpasangan sehingga diperoleh besar sampel sebanyak 32 responden untuk masing-masing kelompok, setelah diperoleh total 64 responden peneliti membagi secara random kedalam dua kelompok yaitu kelompok perlakuan dan kelompok kontrol.

Pada kelompok perlakuan diberikan intervensi berupa edukasi dan pendampingan oleh kader kesehatan "TB Mataho" dengan media pocket book, sedangkan kelompok kontrol mendapatkan penyuluhan kesehatan dari petugas puskesmas dengan media leaflet. Kader kesehatan TB Mataho adalah para penyintas TB yang telah dinyatakan sembuh kemudian mendapatkan 4 sesi paket pelatihan untuk menjadi kader kesehatan TB paru. Setelah menandatangani lembar persetujuan menjadi responden kedua kelompok dilakukan pretest, yang dilanjutkan pemberian intervensi pada kelompok perlakuan, selama pemberian perlakuan penderita $\mathrm{Tb}$ beserta anggota keluarga yang telah memenuhi kriteria dilibatkan, namun demikian pusat analisis (sumber informasi) pada setiap pengumpulan data adalah penderita TB dan/atau anggota keluarga yang berpengaruh berdasarkan struktur keluarga. Setelah pemberian intervensi selesai, 4 minggu kemudian dilakukan posttest pada kedua kelompok.

Data dikumpulkan menggunakan kuesioner kemampuan perawatan diri yang terdiri dari 24 item pertanyaan yang telah dilakukan uji validitas dan reliabilitas dengan nilai cronbach's alpha 0,928. Instrumen disusun dan diadaptasi peneliti dari scala penilaian perawatan diri versi revisi (Appraisal of Self-Care Agency ScaleRevised) [14]. Analisis data bivariat menggunakan uji paired samples test dan Independent samples test dengan bantuan program komputer pada tingkat signifikansi $95 \%(\alpha=0,05)$. Responden yang terlibat dalam penelitian ini terlebih dahulu menandatangani surat persetuan setelah mendapatkan penjelasan (Informed Consent), keterlibatannya bersifat sukarela dan sewaktu-waktu dapat mengundurkan diri tanpa sanksi apapun, semua informasi dan hasil pemeriksaan yang berkaitan dengan responden dijaga kerahasiaannya serta penyajian data tidak akan dihubungkan dengan identitas responden. Penelitian ini telah mendapatkan rekomendasi laik etik dari Komisi Etik Penelitian Kesehatan Universitas Mataram Nomor : 234/UN18.F7/ETIK/2019.

\section{HASIL}

Responden yang terlibat dalam penelitian ini berjumlah 64 yang terdiri dari 32 responden kelompok perlakuan dan 32 responden kelompok kontrol, tidak ada perbedaan karakteristik responden dari segi usia, jenis kelamin, pekerjaan, status perkawinan serta tingkat Pendidikan, seperti dijelaskan dalam tabel 1 . 
Hasil penelitian menunjukan usia responden kelompok perlakuan maupun kelompok kontrol paling banyak pada kelompok umur 36 - 55 tahun, mayoritas berjenis kelamin laki-laki, bekerja sebagai wiraswasta, status perkawinan sudah kawin, dengan tingkat pendidikan Sekolah Menengah Atas.

Hasil uji beda nilai pre-test antara kelompok perlakuan dan kelompok kontrol menggunakan analisis Independent Samples Test, diperoleh nilai $p=0,253(\mathrm{p}>0,05)$ yang berarti tidak ada perbedaan antara kedua kelompok. Selanjutnya uji beda nilai posttest antara kelompok perlakuan dan kelompok kontrol diperoleh nilai $p=0,030$ $(\mathrm{p}<0,05)$ yang berarti ada perbedaan yang bermakna hasil post-test self-care capacity antara kelompok perlakuan dan kelompok kontrol. Hasil penelitian menunjukan ada peningkatan nilai self-care capacity sebelum dan sesudah perlakuan sebesar 9,91 pada kelompok perlakuan dan sebesar 1,22 pada kelompok kontrol, kemudian terdapat perbedaan nilai yang bermakna sebelum dan sesudah intervensi pada kelompok perlakuan ( $p$-value $0,001<0,05$ ), sedangkan pada kelompok kontrol tidak terdapat perbedaan yang bermakna nilai self-care capacity sebelum dan sesudah perlakuan (p-value 0,400>0,05).

Tabel 1

Karakteristik Responden Kelompok Perlakuan dan Kelompok Kontrol

\begin{tabular}{|c|c|c|c|c|c|}
\hline \multirow[t]{2}{*}{ Karakteristik } & \multicolumn{2}{|c|}{$\begin{array}{l}\text { Kelompok } \\
\text { Perlakuan } \\
\end{array}$} & \multicolumn{2}{|c|}{ Kelompok Kontrol } & \multirow[t]{2}{*}{$\mathrm{p}$} \\
\hline & $\mathrm{f}$ & $\%$ & $\mathrm{f}$ & $\%$ & \\
\hline \multicolumn{6}{|l|}{ Kelompok Umur } \\
\hline $14-25$ Tahun & 5 & 15.6 & 4 & 12.5 & \multirow{4}{*}{0,270} \\
\hline 26 - 35 Tahun & 8 & 25.0 & 8 & 25.0 & \\
\hline 36 - 55 Tahun & 10 & 31.3 & 16 & 50.0 & \\
\hline $56-75$ Tahun & 9 & 28.1 & 4 & 12.5 & \\
\hline \multicolumn{6}{|l|}{ Jenis Kelamin } \\
\hline Laki-Laki & 21 & 65.6 & 19 & 59.4 & \multirow[t]{2}{*}{0,612} \\
\hline Perempuan & 11 & 34.4 & 13 & 40.6 & \\
\hline \multicolumn{6}{|l|}{ Jenis Pekerjaan } \\
\hline PNS/TNI/Polri & 1 & 3.1 & 1 & 3.1 & \multirow{5}{*}{0,149} \\
\hline Pegawai Swasta & 1 & 3.1 & 4 & 12.5 & \\
\hline Wiraswasta & 17 & 53.1 & 19 & 59.4 & \\
\hline Petani & 9 & 28.1 & 6 & 18.8 & \\
\hline Pelajar & 4 & 12.5 & 2 & 6.3 & \\
\hline \multicolumn{6}{|l|}{ Status Perkawinan } \\
\hline Kawin & 23 & 71.9 & 24 & 75.0 & \multirow{3}{*}{0,497} \\
\hline Janda / Duda & 3 & 9.4 & 5 & 15.6 & \\
\hline Belum Kawin & 6 & 18.8 & 3 & 9.4 & \\
\hline \multicolumn{6}{|l|}{ Tingkat Pendidikan } \\
\hline Sarjana & 2 & 6.3 & 3 & 9.4 & \multirow{4}{*}{0,675} \\
\hline SMA & 15 & 46.9 & 12 & 37.5 & \\
\hline SMP & 7 & 21.9 & 13 & 40.6 & \\
\hline SD & 8 & 25.0 & 4 & 12.5 & \\
\hline
\end{tabular}


Tabel 2

Perbedaan Rerata Self-care Capacity Kelompok Perlakuan dan Kelompok Kontrol

\begin{tabular}{lccc}
\hline \multirow{2}{*}{ Indikator } & \multicolumn{2}{c}{ Kelompok } & \multirow{2}{*}{ p } \\
\cline { 2 - 3 } & Perlakuan & Kontrol & 0,253 \\
Self-care Capacity hasil pretes, Mean \pm SD & $74.78 \pm 11.730$ & $77.41 \pm 15.240$ & 0 \\
Self-care Capacity hasil postes, Mean \pm SD & $84.69 \pm 12.143$ & $78.63 \pm 14.762$ & 0,030 \\
Paired Samples Test & 0,001 & 0,400 & \\
\hline
\end{tabular}

\section{PEMBAHASAN}

Hasil penelitian ini menunjukkan nilai pretest self-care capacity pada kelompok perlakuan dan kelompok kontrol hampir sama yaitu pada rentang nilai $74-77$. Hasil ini menunjukan bahwa penderita Tb paru pada kelompok perlakuan maupun kelompok kontrol telah memiliki kemampuan dalam perawatan diri, hal ini bisa terjadi sebagai akibat interaksi dengan petugas kesehatan maupun proses belajar terhadap penyakit yang diderita yang menuntut seseorang untuk dapat melakukan pemenuhan terhadap perawatan dirinya secara mandiri [15]. Adanya kemapuan perawatan diri penderita sebelum diberikan perlakuan seperti kesadaran penderita untuk mencari pertolongan segera ketika mengalami gejala batuk, demam maupun sesak napas, penderita memiliki kesadaran untuk menelan obat sampai habis selama masa pengobatan meskipun gejala TB paru sudah tidak dirasakan lagi, kondisi ini sejalan dengan hasil penelitian sebelumnya bahwa kemapuan perawatan diri dibangun melalui penumbuhan kesadaran akan kebutuhan perawatan diri bagi pasien maupun keluarganya dan mereka mengerti manfaatnya, hal ini membuat mereka akan berkomitmen untuk berpartisipasi dalam perawatan [16]. Kebutuhan perawatan diri merupakan dasar terbentuknya koping dan niat untuk perilaku [17] dalam hal ini perilaku perawatan diri.

Analisis lebih lanjut dengan membandingkan nilai self-care capacity sebelum dan sesudah perlakuan pada masing-masing kelompok menunjukan adanya perbedaan nilai yang bermakna sebelum dan sesudah perlakukan pada kelompok perlakuan sedangkan pada kelompok kontrol tidak terdapat perbedaan yang bermakna. Adanya peningkatan nilai ini karena setiap individu mempunyai kekuatan untuk melaksanakan perawatan diri sendiri, kekuatan tersebut dinamakan self care agency. Self care agency dapat berubah setiap waktu dipengaruhi oleh kondisi kesehatan seorang individu [18], pemberian perlakuan untuk meningkatkan self-care capacity penderita pada penelitian ini dilakukan oleh kader kesehatan "Tb Mataho" melalui kunjungan rumah sebanyak tiga kali kunjungan selama rentang waktu 3 minggu, selama perlakuan kader kesehatan juga berbagi pengalaman berupa kisah sukses sebagai penyintas TB dengan penderita dan keluarga untuk menguatkan semangat dalam menjalani pengobatan TB. Intervensi tersebut dimaksudkan untuk meningkatkan kemampuan self care sesuai dengan pendapat Sukartini, dkk, 2017 [19] mengemukakan bahwa integrasi kegiatan mempromosikan perilaku self-care selfefficay merupakan komponen dasar dari pembetukan agen perawatan mandiri, lebih lanjut dikatakan bahwa peralihan aktifitas perawatan mandiri melibatkan kemampuan seseorang untuk penilaian kebutuhan perawatan diri dan melakukan perawatan diri yang konsisten dengan konseptualisasi self-care self-efficacy. Sejalan pula dengan pendapat Breiddal, 2012 [20] bahwa keterampilan perawatan diri harus diwujudkan melalui pemodelan kesadaran diri, pengetahuan diri, dan refleksi diri, diikuti dengan tindakan untuk menemukan keseimbangan. 
Adanya peningkatan self-care capacity hasil post test pada kelompok perlakuan merupakan hasil dari intervensi yang peneliti laksanakan melalui kegiatan home care dimana pada tahap I diberikan penjelasan tentang pengertian, penyebab serta tanda dan gejala TB paru, cara penatalaksanaan, pencegahan komplikasi serta pencagahan penularan TB paru, yang dilanjutkan tahap II dengan mengajarkan keterampilan perawatan diri berupa latihan napas dalam, latihan batuk efektif, tehnik relaksasi dan pengaturan posisi semi fowler dan tahap III penguatan peran keluarga sebagai pengawas minum obat maupun sebagai support system bagi responden, penyusunan rencana tindak lanjut yang meliputi rencana kontrol teratur dan pemanfaatan fasilitas kesehatan. Perlakuan ini dimaksudkan untuk pengalaman belajar dalam menumbuhkan pengetahuan, pemahaman, dan keterampilan serta meningkatkan efficasi diri responden akan perawatan dirinya [13].

Nilai self-care capacity hasil post-test pada kelompok perlakuan cukup beragam dengan standar deviasi 12.143, hal ini erat kaintannya dengan karakteristik responden dari segi usia dimana pada kelompok perlakuan terdapat $28,1 \%$ responden dengan rentang usia antara 56-75 tahun yang masuk kategori usia lanjut, yang dapat mempengaruhi penerimaannya terhadap perlakukan yang diberikan maupun keterlibatannya dalam tindakan perawatan diri, sesuai dengan pendapat Kusnanto dkk (2018) [15] bahwa perawatan diri merupakan fungsi pengatur manusia sebagai perilaku yang dipelajari, yang dilakukan untuk tujuan tertentu, sesuai pula dengan pendapat [21] bahwa untuk dapat terlibat dalam kegiatan perawatan diri, seorang individu perlu berorientasi pada waktu, kesehatan, orang lain, kejadian, dan lingkungan sekitar.

Self-care dapat dipelajari dan diarahkan pada kinerja perilaku spesifik yang dapat mengarah pada peningkatan kesehatan [22]. Perilaku spesifik dalam hal ini antara lain perilaku perawatan diri selama menjalani perawatan pengobatan penyakit yang diderita seperti perawatan TB paru yang biasanya berlangsung selama $6-9$ bulan. Sistem keperawatan mencakup perancangan dan penerapan rencana yang menjembatani kesenjangan yang diidentifikasi antara persyaratan tindakan yang diperlukan untuk pengaturan kehidupan, kesehatan, dan kesejahteraan dan keterbatasan individu dalam kemampuan untuk menyelesaikan tindakan yang diperlukan [15]. Tindakan menjembatani kesenjangan dalam penelitian ini dilakuan peneliti dalam rangka meningkatkan kemampuan self-care capacity penderita TB paru akan perawatan diri yang diidentifikasi sebagai bagian dari upaya perawatan dan pengobatan penyakit TB paru yang deritanya.

Perawatan diri sebagai rangkaian kegiatan yang saling berhubungan yang merupakan respon terhadap sensasi internal dan kesadaran [20]. Hasil penelitian yang menunjukan bahwa kemampuan self care capacity responden masih dalam kategori cukup, hal ini tidak terlepas dari kondisi sakit yang diderita responden karena self care capacity dapat berubah setiap waktu dipengaruhi oleh kondisi kesehatan individu [18]. Perawatan diri merupakan fungsi pengatur manusia sebagai perilaku yang dipelajari, yang dilakukan untuk tujuan tertentu [15], untuk dapat terlibat dalam kegiatan perawatan diri, seorang individu perlu berorientasi pada waktu, kesehatan, orang lain, kejadian, dan lingkungan sekitar, serta memiliki moral, etika, dan nilai sosial, minat dan perhatian khusus, serta kebiasaan hidup sehari-hari yang mempengaruhi kemampuan perawatan diri [21]. Labih lanjut temuan penelitian menunjukan $53,1 \%$ responden kelompok perlakuan memiliki kemampuan self-care capacity dengan kategori baik. Kemampuan yang dimiliki responden tersebut merupakan hasil dari intervensi yang dilakukan peneliti, sesuai dengan pendapat yang mengatakan bahwa keterampilan perawatan diri jarang 
dilakukan atas kemampuan bawaan oleh karena itu pasien dan keluarga memerlukan pendidikan untuk memperoleh pengetahuan dan keterampilan untuk mengelola perawatan mereka di rumah [23].

\section{SIMPULAN}

Kader kesehatan “TB Mataho” yang telah mendapakan pelatihan mampu memberikan pengetahuan, keterampilan perawatan diri serta membangkitkan semangat responden yang mendapatkan intervensi melalui kisah sukses yang mereka bagikan sehingga meningkatkan self-care capacity penderita TB paru beserta keluarganya untuk menyelesaikan pengobatan sampai tuntas. Peneliti merekomendasikan para penyintas TB paru yang memiliki dasar pendidikan menengah keatas dapat dilatih untuk dijadikan kader kesehatan dan berbagi pengalaman sukses mereka kepada penderita TB paru yang masih menjalani program pengobatan.

\section{UCAPAN TERIMAKASIH}

Terimakasih yang sebesar-besarnya kami sampaikan kepada Politeknik Kesehatan Kementerian Kesehatan Mataram yang telah membiayai pelaksanaan penelitian ini, ucapan terimakasih juga kami sampaikan kepada semua pihak yang telah terlibat dalam penelitian ini mulai dari petugas kesehatan di jajaran Dinas Kesehatan Kota Bima, para kader kesehatan TB Mataho, penderita TB beserta keluarganya, semoga sumbangsih semua pihak dicatat sebagai amal ibadah disisi Tuhan yang Maha Esa.

\section{REFERENSI}

[1] Hershkovitz I, Donoghue HD, Minnikin DE, May $H$, Lee OY, Feldman $M$, et al. Tuberculosis origin: The Neolithic scenario. Tuberculosis 2015:1-5. https://doi.org/10.1016/j.tube.2015.02.021.

[2] Sakula A. Robert Koch : centenary of the discovery of the tubercle bacillus, 1882 . Thorax 1982;37:246-51.

[3] WHO. Global Tuberculosis Report 2018.
Geneva: World Health Organization; 2018.

[4] Kemenkes RI. Profil Kesehatan Indonesia Tahun 2017. Jakarta: 2018.

[5] Dinkes Kota Bima. Profil Kesehatan Kota Bima Tahun 2016. Kota Bima: 2017.

[6] Lefevre AM, Ba F, Fielding KL. Effectiveness of a Strategy to Improve Adherence to Tuberculosis Treatment in a Resource-Poor Setting. JAMA 2015;297:380-6.

[7] Datiko DG, Lindtjorn B. Health Extension Workers Improve Tuberculosis Case Detection and Treatment Success in Southern Ethiopia : A Community Randomized Trial. PLoS One 2009;4:1-7.

https://doi.org/10.1371/journal.pone.000544 3.

[8] Theng Y, Chandra S, Ying L, Goh Q, Lwin MO, Foo S. Exploratory qualitative study for community management and control of tuberculosis in India. Acta Trop 2014;132:98-105. https://doi.org/10.1016/j.actatropica.2013.12. 014.

[9] Rithpho P, Grimes DE, Grimes RM, Nantachaipan P, Senaratana W. A Nursing Intervention to Enhance the Self-Care Capacity of Nondisclosed Persons Living With HIV in Thailand. J Assoc Nurses AIDS Care 2013;24:512-20.

https://doi.org/10.1016/j.jana.2012.11.002.

[10] Nihayati HE, Nurhanifah L, Krisnana I. The Effect of Psychoeducation on Self-Efficacy and Motivation for Taking Treatment in Breast Cancer Patients ( Ca Mammae ) Hanik Endang Nihayati , Laeli Nurhanifah and Ilya Krisnana. J Ners 2021;16.

[11] Kangovi S, Mitra N, Grande D, White ML, Mccollum S, Sellman J, et al. Patient-Centered Community Health Worker Intervention to Improve Posthospital Outcomes A Randomized Clinical Trial. JAMA Intern Med 2015;174:53543.

https://doi.org/10.1001/jamainternmed.2013. 14327.

[12] Mohr E, Snyman L, Mbakaz Z, Caldwell J, Deazevedo V, Kock Y, et al. "Life continues ": Patient, health care and community care workers perspectives on self- administered treatment for rifampicin- resistant tuberculosis in Khayelitsha, South Africa. PLoS One 2018:116.

https://doi.org/https://doi.org/10.1371/jour nal.pone.0203888 September.

[13] Solikhah MM, Nursasi AY, Wiarsih W. The relationship between family's informational support and self-efficacy of pulmonary tuberculosis client. Enferm Clin 2019. https://doi.org/10.1016/j.enfcli.2019.04.062.

Muhtar Muhtar / The effect of "TB Mataho" health cadres in improving self-care capacity of patients with pulmonary tuberculosis 
[14] Guo L, Zauszniewski JA, Ding X, Zhang L, Gao H, Guo $Q$, et al. The Appraisal of Self-Care Agency Scale-Revised (ASAS-R): Reliability and Validity Among Older Chinese People. West J Nurs Res 2017;39:1459-76. https://doi.org/10.1177/0193945916672821.

[15] Kusnanto K, Sari NPWP, Harmayetty H, Efendi F, Gunawan J. Self-care model application to improve self-care agency, self-care activities , and quality of life in patients with systemic lupus erythematosus. J Taibah Univ Med Sci 2018;13:472-8.

https://doi.org/10.1016/j.jtumed.2018.07.002

[16] Sukartini T, Minarni I, Asmoro CP. Family Support, Self-efficacy, Motivation, and Treatment Adherence in Multidrug-resistant Tuberculosis Patients. Proc Ofthe 9th Int Nurs Conf 2019:178-82. https://doi.org/10.5220/0008322301780182.

[17] Mufarokhah H, Putra ST, Dewi YS. Self Management Program Meningkatkan Koping, Niat Dan Kepatuhan Berobat Pasien PJK. J Ners 2014;11:56-62.

[18] Parker ME, Smith MC. Nursing Theories \&
Nursing Practice. Third. Philadelphia: F.A. Davis Company; 2010.

[19] Sukartini T, Ramadhani F, Hidayati L. Relationship Between Proactive Coping And Self-Care Management In Patient With Pulmonary Tuberculosis. J Ners 2017;12:2338.

[20] Breiddal SMF. Self-Care in Palliative Care: A Way of Being. Illness, Cris Loss 2012;20:5-17. https://doi.org/10.2190/IL.20.1.b.

[21] White ML, Peters R, Schim SM. Spirituality and Spiritual Self-Care. Nurs Sci Q 2011;24:48-56. https://doi.org/10.1177/0894318410389059.

[22] Mashudi S, Yusuf A. Family Coping Strategies to Improve the Health of Family Members Living with Schizophrenia. J Ners 2021;16.

[23] Veronovici NR, Lasiuk GC, Rempel GR, Norris CM. Discharge education to promote selfmanagement following cardiovascular surgery: An integrative review. Eur J Cardiovasc Nurs 2014;13:22-31. https://doi.org/10.1177/1474515113504863. 